\title{
Inhibition of Enzymes which Interact with Citrate by (-)Hydroxycitrate and 1,2,3,-Tricarboxybenzene
}

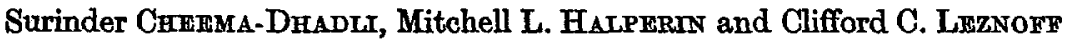

Department of Medicine, University of Toronto, and Department of Chemistry, York University, Downsview

The effects of two citrate analogues, (-)hydroxycitrate and 1,2,3-tricarboxybenzene, were studied using rat liver enzymes which interact with citrate.

The most pronounced effect of 1,2,3-tricarboxybenzene was inhibition of acetyl-CoA carboxylase $\left(K_{1} 20 \mu \mathrm{M}\right)$. It also inhibited the mitochondrial citrate transporter $(50 \%$ inhibition at $3 \mathrm{mM})$, but was not a substrate for this transporter.

ATP-citrate lyase was markedly inhibited by both free (-)hydroxyeitrate $\left(K_{1} 8 \mu \mathrm{M}\right)$ and (-)hydroxycitrate lactone $\left(K_{1} 50\right.$ to $\left.100 \mu \mathrm{M}\right)$. Acetyl-CoA carboxylase was activated by both the forms of (-)hydroxycitrate $\left(K_{\Omega} 0.7 \mathrm{mM}\right.$ and $1.6 \mathrm{mM}$, respectively). (-)Hydroxycitrate is a substrate for the mitochondrial citrate transporter, but its rate of transport is less than $10 \%$ of that of citrate.

Other citrate metabolizing enzymes also were inhibited by 1,2,3-tricarboxybenzene and (-)hydroxycitrate but much higher concentrations were required.

The importance of citrate as a regulator and substrate in intermediary metabolism has received considerable attention. It is an intermediate in the tricarboxylic acid cycle and in the pathway for biosynthesis of lipids. It is an inhibitor of phosphofructolkinase [1-3] and, therefore, a potential regulator of glycolysis. Activation of acetyl-CoA carboxylase $[4-6]$ by citrate may stimulate the fatty acid biosynthetic pathway. Citrate has also been shown to inhibit pyruvate dehydrogenase $[7,8]$, an action which could limit pyruvate oxidation in fasting.

Two analogues of citrate which inhibit specific steps in citrate metabolism have recently been reported $[9,10]$. (-)Hydroxycitrate is an inhibitor of ATP-citrate lyase [9] and 1,2,3-tricarboxybenzene is an inhibitor of the mitochondrial citrate transporter [10]. We have studied the effects of these inhibitors on the enzymes and transport system known to be involved in the intermediary metabolism of citrate. These studies were undertaken to allow more rational interpretation of their effects in biological systems.

Enzymes. Acetyl-CoA carboxylase (EC 6.4.1.2); citrate(isocitrate)hydro-lyase or aconitase (EC 4.2.1.3); ATP-citrate lyase (EC 4.1.3.8); eitrate synthase (EC 4.1.3.7); NAD.isooitrate dehydrogenase (EC 1.1.1.41); NADP-isocitrate dehydrogenase (EC 1.1.1.42); phosphofructokinase (EC2.7.1.11) pyruvate dehydrogenase (EC 1.2.4.1).

\section{MATERIALS AND METHODS}

Male Wistar rats weighing $110-150 \mathrm{~g}$ were fed ad libitum until sacrificed. (-)Hydroxycitrate lactone was a kind gift from Dr Y. S. Lewis (Mysore, India). 1,2,3-Tricarboxybenzene was obtained from $K$. and K. Laboratories (Plainview, N. Y.). [1-14C]Pyruvate and sodium [14C]bicarbonate were purchased from Amersham-Searle (Don Mills, Ontario). Aldolase, glycerol-1-phosphate dehydrogenase, triosephosphate isomerase, NADP+-linked isocitrate dehydrogenase, metabolic intermediates and the pyridine nucleotides were obtained from Boehringer Mannheim GmbH (New York, N.Y.). Acetyl-CoA and bovine serum albumin were obtained from Sigma Chemical Co. (St. Louis, Missouri) and coenzyme A was obtained from Calbiochem (Los Angeles, California).

\section{Preparation and Assay of Enzymes from Rat Liver}

Protein was determined by the method of Warburg and Christian [11] or Lowry et al. [12]. Enzymes were used for kinetic studies within $1-2$ days after their preparation.

Citrate synthase was prepared up to the first $\left(\mathrm{NH}_{4}\right)_{2} \mathrm{SO}_{4}$ fractionation with a specific activity of 0.63 units/mg protein, and assayed by the method of Shepherd and Garland [13]. 
Aconitase was prepared by the method of Fansler and Lowenstein [14], with slight modifications. The intramitochondrial enzyme was obtained by suspending a mitochondrial pellet [15] in four times its volume of $15 \mathrm{mM}$ tricarballylate-Tris buffer, $\mathrm{pH}$ 7.8. The suspension was sonicated at $20 \mathrm{kHz} / \mathrm{s}$ for $8 \mathrm{~min}$ $\left(5-10^{\circ} \mathrm{C}\right)$. Insoluble material was removed by centrifugation at $13000 \times g$ for $15 \mathrm{~min}$. Solid $\left(\mathrm{NH}_{4}\right)_{2} \mathrm{SO}_{4}$ was added to the supernatant to $50 \%$ of saturation. After centrifugation at $13000 \times g$ for $15 \mathrm{~min}$ the precipitate was discarded and the supernatant assayed for aconitase activity. The enzyme had a specific activity of 24 units/mg protein. The kinetic parameters were determined using a spectrophotometric assay [14] or a fluorometric assay coupling this reaction to NADP+-linked isocitrate dehydrogenase.

$A T P$-citrate lyase was purified to the $25-45 \%$ $\left(\mathrm{NH}_{4}\right)_{2} \mathrm{SO}_{4}$ fractionation with a specific activity of 0.39 unit/mg protein by the method of Takeda et al. and assayed fluorometrically [16].

$N A D P+$-linked isocitrate dehydrogenase (intramitochondrial and extramitochondrial) was purified as follows. Rat livers were homogenized in $0.1 \mathrm{M}$ potassium phosphate buffer $\mathrm{pH} 7.6$ containing $0.5 \mathrm{M}$ sucrose and centrifuged at $1000 \times g$ for $10 \mathrm{~min}$. The supernatant was centrifuged again for $10 \mathrm{~min}$ at $13000 \times g$ to obtain a mitochondrial pellet. This pellet was suspended in 3 volumes of $0.1 \mathrm{M}$ potassium phosphate buffer $\mathrm{pH} 7.6$, sonicated at $20 \mathrm{kHz} / \mathrm{s}$ for $6 \min \left(5-10^{\circ} \mathrm{C}\right)$ and centrifuged at $13000 \times g$ for $30 \mathrm{~min}$. Dithiothreitol $(0.3 \mathrm{mM})$ and EDTA $(1 \mathrm{mM})$ were added to this supernatant, then $\left(\mathrm{NH}_{4}\right)_{2}$ $\mathrm{SO}_{4}$ was added to $50 \%$ saturation, After centrifugation at $10000 \times g$ for $15 \mathrm{~min}$, the pellet was discarded and additional ammonium sulphate added to $80 \%$ of saturation. After centrifugation, the precipitate was dissolved in a minimum volume of $0.1 \mathrm{M}$ Tris-HCl pH 7.4 containing $0.3 \mathrm{mM}$ dithiothreitol and $1 \mathrm{mM}$ EDTA. The specific activity of the enzyme was 203 units/mg protein. The supernatant obtained from the initial $13000 \times g$ centrifugation was centrifuged again at $105000 \times g$ for $60 \mathrm{~min}$. A $50-80 \%$ ammonium sulphate fractionation was carried out, as just described for the soluble mitochondrial enzyme, to a specific activity of $330 \mathrm{units} / \mathrm{mg}$ protein. Both enzymes were assayed fluorimetrically [17].

$N A D+$-linked isocitrate dehydrogenase was prepared from rat liver mitochondria (specific activity 17 units/mg) and assayed as described by Martin and Denton [17].

Acetyl-CoA carboxylase was assayed in an 80000 $\times g$ supernatant by the sodium $\left.{ }^{14} \mathrm{C}\right]$ bicarbonate fixation method [18].

Phosphofructokinase was prepared as a $30-50 \%$ $\left(\mathrm{NH}_{4}\right)_{2} \mathrm{SO}_{4}$ fraction (specifio activity 7.9 units $/ \mathrm{mg}$ protein) by the method of Kemp [19], with the exception that the heat step was omitted. It was assayed fluorometrically [3].
Pyruvate dehydrogenase was assayed in rat liver mitochondria after homogenization of the mitochondrial pellet in hypotonic solution (10 $\mathrm{mM}$ potassium phosphate, $1 \mathrm{mM}$ EDTA, $1 \mathrm{mM}$ dithiothreitol, $1 \%$ fatty-acid-poor bovine serum albumin, $\mathrm{pH}$ 7.4) [20].

Mitochondrial-tricarboxylate-exchange studies were carried out using the methods of Robinson et al. [21] for both $\left[{ }^{14} \mathrm{C}\right]$ citrate loading and [14C]citrate/citrate exchanges.

\section{The Purification of (-)Hydroxycitric Acid}

(-)Hydroxycitric acid was dissolved in ether and filtered to remove insoluble impurities. Purified (-)hydroxycitric acid lactone, m.p. $178^{\circ} \mathrm{C}$, was recrystallized from ether as described by Lewis and Neelakanton [22]. Aqueous solutions of potassium salts of the free acid were obtained by raising the $\mathrm{pH}$ to 12 with $\mathrm{KOH}$ for $10 \mathrm{~min}$ at $25^{\circ} \mathrm{C}$ prior to neutralization.

$\mathcal{I}$ unit of enzyme activity is defined as the amount causing transformation of $1 \mu \mathrm{mol}$ substrate per min at $25{ }^{\circ} \mathrm{C}$ under optimal conditions of measurement.

\section{RESULTS AND DISCUSSION \\ Phosphofructokinase}

As shown previously $[1-3]$, citrate inhibited phosphofructokinase (Table 1). Phosphofructokinase was also inhibited by 1,2,3-tricarboxybenzene and (-)hydroxycitrate, but the concentrations required for $50 \%$ decrease in activity were approximately 1.2-fold greater than for citrate (3.9 mM) (Table 1).

\section{Acetyl.CoA Carboxylase}

Activation of acetyl-CoA carboxylase by citrate was inhibited by 1,2,3-tricarboxybenzene is a manner competitive with citrate ( $K_{1}$ approx. $20 \mu \mathrm{M}$, Fig.1). In the absence of citrate, 1,2,3-tricarboxybenzene had no effect. (-)Hydroxycitrate activated acetylCoA carboxylase (Fig.2), as reported previously $[23,24]$.

\section{The Mitochondrial Tricarboxylate Carrier and the Intramitochondrial Enzymes}

Previous studies have shown that 1,2,3-tricarboxybenzene is a competitive inhibitor of citrate transport in rat-liver mitochondria with a $K_{1}$ of $3 \mathrm{mM}$. [10] (Table 2B). (-)Hydroxyoitrato did not inhibit the carrier but was a weak substrate. The $K_{\mathrm{m}}$ appears to be of the same order of magnitude as that for citrate, but the $V$ was much lower (Table $2 A$ ). As a weak substrate for this carrier, (-)hydroxy. citrate may enter the mitochondria where it could affect the intramitochondrial citrate-metabolizing enzymes. Free (-)hydroxyoitrate inhibited intra- 
Table 1. Effects of citrate, 1,2,3-tricarboxybenzene and (-)hy. droxycitrate on phosphofructokinase from rat liver

The assay mixture $(1 \mathrm{ml})$ contained $0.1 \mathrm{M}$ Tris- $\mathrm{HCl} \mathrm{pH} 7.0$, $0.03 \mathrm{mM}$ EDTA, $10.0 \mathrm{mM} \mathrm{MgCl}_{2}, 0.06 \mathrm{mM}$ NADH, $0.06 \mathrm{mM}$ dithiothreitol, $0.01 \mathrm{M} \mathrm{NH}_{4} \mathrm{Cl}, 0.2 \mathrm{mM}$ ATP, $0.3 \mathrm{mM}$ fructose. 6-phosphate, $30 \mu \mathrm{g}$ aldolase, $5 \mu \mathrm{g}$ glycerol-phosphate dehydrogenase and $5 \mu \mathrm{g}$ triosephosphate isomerase in addition to the extract from rat liver. The reaction was started by the addition of fructose 6-phosphate. Each assay was studied in duplicate using six concentrations of each inhibitor

\begin{tabular}{lc}
\hline $\begin{array}{l}\text { Addition to } \\
\text { assay mixture }\end{array}$ & $\begin{array}{c}\text { Conoentration for } \\
50 \% \text { inhibition }\end{array}$ \\
& $\mathrm{mM}$ \\
Citrate & 3.9 \\
1,2,3-Tricarboxybenzene & 4.7 \\
(-)Hydroxycitrate (free) & 5.0 \\
(-)Hydroxycitrate & $\mathbf{3 . 6}$ \\
\hline
\end{tabular}

Table 2. Effect of citrate, (-)hydroxycitrate and 1,2,3-tricarboxybenzene on the mitochondrial citrate transporter of ratliver mitochondria

Incubations were performed at $8{ }^{\circ} \mathrm{C}$ as described by Robinson et al. [21]. The exchanges were started by the addition of [14C]citrate-loaded mitochondria. After $45 \mathrm{~s}$, citrate transport was terminated by the rapid addition of 1,2,3-tricarboxybenzene $(50 \mathrm{mM})$. The constants reported were calculated from Lineweaver-Burk plots, using 7 concentrations of each A

\begin{tabular}{|c|c|c|}
\hline Addition & $\mathrm{Km}$ & $\begin{array}{l}\text { Rate of citrate } \\
\text { exohange, } V_{\max }\end{array}$ \\
\hline & $\mathbf{m M}$ & 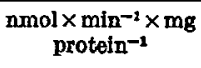 \\
\hline Citrate & 0.22 & 3.5 to $8.0(12)$ \\
\hline $\begin{array}{l}\text { (-) Hydroxycitrate } \\
\text { (free) }\end{array}$ & 0.35 & 0.32 \\
\hline $\begin{array}{l}\text { (-) Hydroxycitrate } \\
\text { (lactone) }\end{array}$ & 0.30 & 0.17 \\
\hline \multicolumn{3}{|l|}{ B } \\
\hline \multirow[t]{2}{*}{ Addition } & $\begin{array}{c}\text { Type of } \\
\text { inhibition }\end{array}$ & $\begin{array}{l}\text { Concentration } \\
\text { required for } \\
50 \% \text { inhibition }\end{array}$ \\
\hline & & $\mathbf{m a M}$ \\
\hline $\begin{array}{l}\text { Citrate + 1,2,3-tri- } \\
\text { carboxybenzene }\end{array}$ & competitive & 3.0 \\
\hline $\begin{array}{l}\text { Citrate + }(-) \text { hydroxy- } \\
\text { citrate (free) }\end{array}$ & no inhibition & - \\
\hline $\begin{array}{l}\text { Citrate + (-)hydroxy- } \\
\text { citrate (lactone) }\end{array}$ & no inhibition & - \\
\hline
\end{tabular}

mitochondrial NADP+-linked isocitrate dehydrogenase with a $K_{1}$ of $0.25 \mathrm{mM}$ and aconitase with a $K_{1}$ of $0.28 \mathrm{mM}$ (Table 3). Intramitochondrial aconitase was also inhibited by (-)hydroxycitrate lactone $\left(K_{1} 0.3 \mathrm{mM}\right)$. Neither (-)hydroxyoitrate nor 1,2,3tricarboxybenzene inhibited the $\mathrm{NAD}^{+}$-linked isocitrate dehydrogenase. In fact, slight activation of

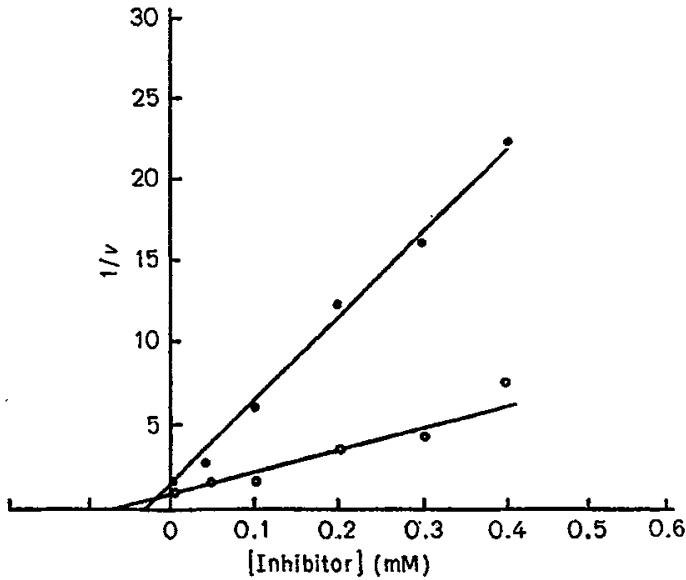

Fig.1. Dixon plot to show the effect of 1,2,3-tricarboxybenzene on citrate-activated acetyl-CoA carboxylase activity. AcotylCoA carboxylase was assayed by the $\left[{ }^{14} \mathrm{C}\right]$ bicarbonate fixation assay [18]. Supernatant $(0.02 \mathrm{ml})$ was preincubated at $37^{\circ} \mathrm{C}$ for $30 \mathrm{~min}$ in the presence of potassium citrate. The preincubation mixture also contained $50 \mathrm{mM}$ Tris-HCl $\mathrm{pH} \mathrm{7.5}$, $20 \mathrm{mM} \mathrm{MgCl}, 1.0 \mathrm{mM}$ 2-mercaptoethanol, and $0.9 \mathrm{mg} / \mathrm{ml}$ bovine serum albumin in a total volume of $0.7 \mathrm{ml}$. The reaction was started by adding $0.40 \mathrm{mM} \mathrm{NaH}{ }^{14} \mathrm{CO}_{3}(10-\mu \mathrm{Ci})$, $2 \mathrm{mM}$ ATP, and $0.14 \mathrm{mM}$ acetyl-CoA to the preincubation mixture and then incubated for 2 min. Velocity $(v)$ was measured as $\mathrm{NaH}^{14} \mathrm{CO}_{\mathrm{s}}$ final (nmol min-1 $\mu \mathrm{g}^{-1}$ ). 1,2,3-Tricarboxybenzene (inhibitor) was added to the preincubation mixture in the presence of potassium citrate, $3 \mathrm{mM}(\bullet)$ and $7 \mathrm{mM}(0)$

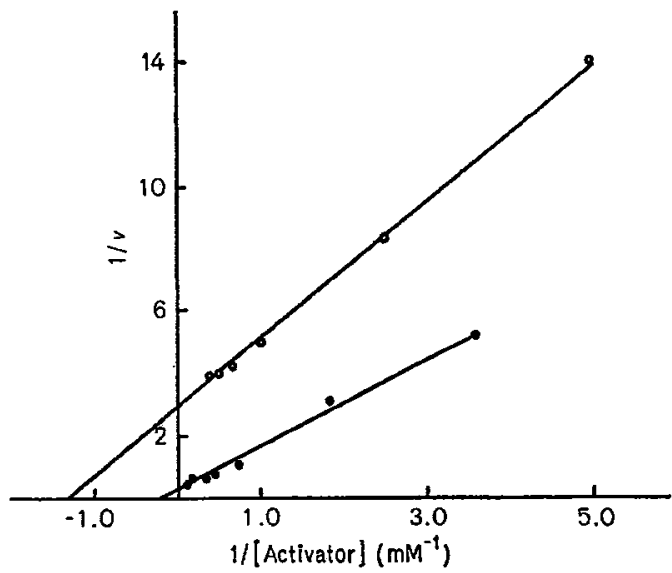

Fig. 2. Effect of citrate and (-)hydroxycitrate on acetyl-CoA carboxylase activity from rat liver. Conditions of assay were those deseribed for Fig. 1. The $K_{\mathrm{m}}$ values were calculated to be $6.7 \mathrm{mM}$ for citrate (-๑) and $0.7 \mathrm{mM}$ for free (-)hydroxycitrate $(\mathrm{O}-\mathrm{O})$. Not shown in the figure, the $K_{\mathrm{m}}$ for the lactone (-)hydroxycitrate was $1.6 \mathrm{mM}$

this enzyme by $(-)$ hydroxycitrate was observed at low isocitrate concentrations. This enzyme can also be activated by citrate [25-27]. The $K_{1}$ values for the other intramitochondrial enzymes that are inhibited by these compounds are very high (Table 3), 
Table 3. $\mathrm{K}_{1}$ values for inhibition by (-)hydroxycitrate and 1,2,3-tricarboxybenzene of enzyme with citrate and isocitrate as substrate or product

The various enzymes were assayed as described in Methods. The kinetic constants were calculated from Dixon plots using a minimum of six inhibitor concentrations

\begin{tabular}{|c|c|c|c|c|}
\hline Enzyme & Sabstrate & $\underset{\text { (free) }}{(-) \text { Hydroxycitrate }}$ & $\begin{array}{c}\text { (-)Hydroxyoitrate } \\
\text { (laetone) }\end{array}$ & $\begin{array}{c}\text { 1,2,3-Tri- } \\
\text { carboxybenzene }\end{array}$ \\
\hline & & $\mathbf{m M}$ & $\mathrm{mM}$ & $\mathrm{mM}$ \\
\hline Citrate synthase & $\begin{array}{l}\text { oxalacetate } \\
\text { acetyl-CoA }\end{array}$ & $\begin{array}{l}3.0 \\
\mathbf{3 . 5}\end{array}$ & $\begin{array}{l}5.0 \\
3.0\end{array}$ & $\begin{array}{l}1.5 \\
0.7\end{array}$ \\
\hline Aconitase & cis-aconitate & 0.28 & 0.3 & $3.7^{\mathrm{a}}$ \\
\hline Citrate lyase & citrate & 0.008 & $0.05-0.1$ & no effeot \\
\hline $\begin{array}{l}\text { Isocitrate dehydrogenase NADP+-linked } \\
\text { (mitochondrial) }\end{array}$ & isocitrate & 0.25 & 2.4 & 1.6 \\
\hline $\begin{array}{l}\text { Isocitrate dehydrogenase NADP+-linked } \\
\text { (extramitochondrial) }\end{array}$ & isooitrato & 0.4 & 2.0 & 2.2 \\
\hline Isocitrate dehydrogenase $\mathrm{NAD}^{+}-$linked & isocitrate & $\begin{array}{l}\text { no inhibition } \\
\text { (slight activation at } \\
\text { low isocitrate) }\end{array}$ & $\begin{array}{l}\text { no inhibition } \\
\text { (slight activation at } \\
\text { low isocitrate) }\end{array}$ & no effect \\
\hline
\end{tabular}

* All inhibitors were competitive except this one, which was non-competitive.

e.g. citrate synthase, aconitase and NADP+-linked isocitrate dehydrogenase.

\section{ATP.Citrate Lyase}

Competitive inhibition of ATP-citrate lyase by (-)hydroxycitrate [9] at low concentrations (8 $\mu \mathrm{M})$ has been confirmed in this study. 1,2,3-Tricarboxybenzene did not affect this enzyme (Table 3 ).

\section{Pyruvate Dehydrogenase}

As reported previously $[7,8]$, pyruvate dehydrogenase prepared from rat-liver mitochondria was inhibited completely by citrate $(4.5 \mathrm{mM}$, Table 4$)$. The concentrations of (-)hydroxycitrate and 1,2,3tricarboxybenzene required to inhibit pyruvate dehydrogenase were greater than that required for citrate (Table 4). (-)Hydroxycitrate was somewhat more inhibitory than 1,2,3-tricarboxybenzene. Since neither inhibitor should be expected to reach these concentrations inside the mitochondria, these inhibitors are unlikely to affect pyruvate dehydrogenase in intact cell experiments.

\section{General Comments}

There are major problems with the use of metabolic inhibitors in the study of regulatory phenomenon. A compound is required whose site and mode of action are specific. Also, the concentration of this agent required to achieve this action should be known as higher concentrations of these inhibitors might have additional sites of action.

1,2,3-Tricarboxybenzene is a very potent inhibitor of acetyl-CoA carboxylase $\left(K_{1} 20 \mu \mathrm{M}\right.$, Fig. 1$)$.
Table 4. Inhibition of rat-liver pyruvate dehydrogenase by citrate. (-) hydroxycitrate and 1,2,3-tricarboxybenzene The enzyme was first converted to the phosphorylated (in. active) form by preincubation in the presence of $1 \mathrm{mM}$ ATP for $30 \mathrm{~min}$ at room temperature. The enzyme was then activated in the presence of $10 \mathrm{mM} \mathrm{MgCl}_{2}$ and $9 \mathrm{mM} \mathrm{CaCl}$ for $5 \mathrm{~min}$ at room temperature. The control enzyme value was $17.8 \pm 2.7 \mathrm{nmol}\left[1-{ }^{14} \mathrm{C}\right]$ pyruvate $\rightarrow{ }^{14} \mathrm{CO}$, per $2 \mathrm{~min}$. The tricarboxylates were added to the activation mixture and the enzyme was then assayed 5 min later. Results represent the mean \pm S.E.M. of 4 experiments, each experiment with quadruplicate observations

\begin{tabular}{|c|c|c|}
\hline $\begin{array}{l}\text { Addititon of trioarboxylate } \\
\text { to activation mixture }\end{array}$ & $\begin{array}{l}\text { Concen- } \\
\text { tration }\end{array}$ & Activity \\
\hline & $\mathrm{mM}$ & $\%$ \\
\hline $\begin{array}{l}\text { No addition (control) } \\
\text { Citrate }\end{array}$ & $\begin{array}{l}0.5 \\
1.5 \\
4.5\end{array}$ & $\begin{aligned} & 100 \\
& 77 \pm 10.8 \\
& 36 \pm 11.8^{\mathrm{a}} \\
&-6 \pm 8.2^{\mathrm{a}}\end{aligned}$ \\
\hline $\begin{array}{l}\text { (-)Hydroxycitrate (hydrolyzed } \\
\text { or lactone) }\end{array}$ & $\begin{array}{l}0.5 \\
0.5 \\
1.5 \\
4.5\end{array}$ & $\begin{array}{l}97 \pm 18.2 \\
97 \pm 18.2 \\
75 \pm 17.0 \\
59 \pm 10.0^{\mathrm{a}}\end{array}$ \\
\hline 1,2,3-Tricarboxybenzene & $\begin{array}{l}0.5 \\
1.5 \\
4.5\end{array}$ & $\begin{array}{l}86 \pm 7.2 \\
84 \pm 6.6 \\
71 \pm 8.2^{\mathrm{a}}\end{array}$ \\
\hline
\end{tabular}

$-P<0.01$.

If its cytosolic concentration were to rise to the $\mathrm{mM}$ range, inhibition of the mitochondrial citrate transporter (Table 2), phosphofructokinase (Table 1), extramitochondria] NADP+-linked isocitrate dehydrogenase and aconitase (Table 3) would occur. Since this agent is unlikely to enter rat-liver mito- 
chondria (Table 2), one would not anticipate direct effects on intramitochondrial enzymes.

(-)Hydroxycitrate is a potent inhibitor of ATP. citrate lyase ( $K_{1} 8 \mu \mathrm{M}$, Table 3 ) and has been used in studies on the control of lipogenesis [11,28-31]. Higher cytosolic concentrations might activate acetyl-CoA carboxylase $\left(K_{\mathrm{a}} 700 \mu \mathrm{M}\right.$, Fig. 2$)$ and also enter the mitochondrion on the citrate transporter $\left(K_{\mathrm{m}} 350 \mu \mathrm{M}\right.$, Table 2). Once inside the mitochondrion, inhibition of NADP+-linked isocitrate dehydrogenase and aconitase (Table 3) could occur. At concentrations in the $\mathrm{mM}$ range, citrate synthase (Table 3), pyruvate dehydrogenase (Table 4) and phosphofructokinase (Table 1) might also be inhibited.

In addition, 1,2,3-tricarboxybenzene and (-). hydroxycitrate, like citrate, can chelate divalent metal cations like $\mathrm{Mg}^{2+}, \mathrm{Mn}^{2+}$ and $\mathrm{Ca}^{2+}$ which could produce other non-specific metabolic actions.

\section{Conclusions}

1,2,3-Tricarboxybenzene may be a suitable agent to study the cholesterol biosynthetio pathway in rat liver with fatty acid synthesis inhibited. This would require a cytosolic concentration 1,2,3-tricarboxybenzene which was high enough to inhibit acetylCoA carboxylase $\left(K_{1}\right.$ approx. $\left.20 \mu \mathrm{M}\right)$ but low enough so as not to inhibit the mitochondrial citrate transporter ( $K_{1}$ approx. $2 \mathrm{mM}$ ) or phosphofructokinase $\left(K_{1}\right.$ approx. $5 \mathrm{mM}$ ). This agent is unlikely to enter rat-liver mitochondria because it is not a substrate for the citrate transporter.

In studies using (-)hydroxycitrate as a specific inhibitor of ATP-citrate lyase ( $K_{1}$ approx. $8 \mu \mathrm{M}$ ), activation of acetyl-CoA carboxylase $\left(K_{\mathrm{a}}\right.$ approx. $700 \mu \mathrm{M})$ and entry into the mitochondrion on the citrate transporter $\left(K_{\mathrm{m}} 350 \mu \mathrm{M}\right)$ should be considered in interpreting results. Once inside the mitochondrion, this agent could inhibit aconitase and NADP+-linked isocitrate dehydrogenase ( $K_{1}$ values $250-280 \mu \mathrm{M}$ ). High cytosolic concentrations could also inhibit phosphofructokinase.

The authors are very grateful to Dr A. Goodridge, Dr W. M. Taylor and Dr G. M. Schiller for helpful advice and discussions, and to Mrs L. Richardson and Mrs I. Shustik for skilled technical assistance. This work was supported in part by grants from the Medical Research Council of Canada, St. Michael's Research Society, Banting Research Foundation, the Canadian Diabetic Association and the Atkinson Charitable Foundation.

\section{REFERENCES}

1. Parmeggiani, A. \& Bowman, R. H. (1963) Biochem. Biophys. Res. Commun. 12, 268-273.

2. Garland, P. B., Randle, P. J. \& Newsholme, E. A. (1963) Nature (Lond.) 200, 169-170.

3. Passonneau, J. V. \& Lowry, O. H. (1963) Biachem. Biophys. Res. Commun. 13, 372-379.

4. Matsuhashi, M., Matsuhashi, S. \& Lynen, F. (1964) Biochem. Z. 340, 263-289.

5. Lane, M. D. \& Moss, J. (1971) Metabolic Pathuays, 5, 23.

6. Vagelos, P. R. (1971) Curr. Top. in Cell. Regul. 4, $119-166$.

7. Silbert, C. K. \& Martin, D. B. (1968) Biochem. Biophys. Res. Commun. 31, 818-824.

8. Taylor, W. M. \& Halperin, M. L. (1973) J. Biol. Chem. in press.

9. Watson, J. A., Fang, M. \& Lowenstein, J. M. (1969) Arch. Biochem. Biophys. 135, 209-217.

10. Robinson, B. H., Williams, G. R., Halperin, M. L. \& Loznoff, C. C. (1971) Eur. J. Biochem. 20, 65-71.

11. Warburg, 0. \& Christian, W. (1941) Biochem. Z. 310 , $384-421$.

12. Lowry, O. H., Rosebrough, N. J., Farr, A. L. \& Randall, R. J. (1951) J. Biol. Chem. 193, 265-275.

13. Shepherd, D. \& Garland, P. B. (1969) Methods Enzymol. 13, 11-16.

14. Fansler, B. \& Lowenstein, J. M. (1960) Methods Enzymol. $13,26-30$

15. Schneider, W. C. \& Hageboom, H. G. (1950) J. Biol. Chem. 183, 123-128.

16. Takeda, Y., Suzuki, F. \& Inoue, H. (1969) Methods Enzymol. 13, 153-160.

17. Martin, B. R. \& Denton, R. M. (1970) Biochem. J. 117, $881-898$.

18. Majerus, P. W., Jacobs, R. \& Smith, M. B. (1968) $J$. Biol. Chem. 243, 23588-3595.

19. Kemp, R. G. (1971) J. Biol. Chem. 246, 245-252.

20. Taylor, S. I., Mukjerjee, C. \& Jungas, R. L. (1973) J. Biol. Chem. 248, 73-81.

21. Robinson, B. H., Williams, G. R., Halperin, M. L. \& Leznoff, C. C. (1970) Eur. J. Biochem. 15, 263-272.

22. Lewis, Y. S. \& Neelakanton, S. (1965) Phytochemistry, 4 , 619-625.

23. Barth, C., Haokenschmidt, J., Ullman, H. \& Decker, K. (1972) FEBS Lett. 22, 343-346.

24. Hackenschmidt, J., Barth, C. \& Decker, K. (1972) FEBS Lett. 27, 131-133.

25. Sanwall, B. D. \& Cook, R. (1966) Biochemistry, 5, 886894.

26. Cox, G. F. \& Davies, D. D. (1967) Biochem. J. 105, $729-734$.

27. LAJohn, H. B., McCrea, B. E., Suznuki, I. \& Jackson, S. (1969) J. Biol. Chem. 244, 2484-2493.

28. Sullivan, A. C., Hamilton, J. G., Miller, O. N. \& Wheatley, V. R. (1972) Arch. Biochem. Biophys. 150, 183 190.

29. Lowenstein, J. M. (1970) in Essays in Cell Metabolism (Bartley, W., Kornberg, H. L. \& Quayle, J. R., eds) p. 153, Wiley, Now York.

30. Lowenstein, J. M. (1971) J. Biol. Chem. 246, 629-632.

31. Watson, J. A. \& Lowenstein, J. M. (1970) J. Biol. Chem. $245,6993-6002$.

S. Cheema-Dhadli and M. L. Halperin, Department of Medicine, Medical Sciences Building, University of Toronto, Toronto, Ontario, Canada M5S 1 A8

C. C. Leznoff, Department of Chemistry, York University, Downsview, Canada M3J 1P3 